\title{
ALTERNATIVES OF FOREIGN TRADE POLICY IN THE DEVELOPING COUNTRIES IN THE CONTEXT OF SEARCHING THE WAYS TO REDUCE POVERTY
}

\begin{abstract}
The problem of developing countries' choice of the optimal foreign trade strategy through the prism of poverty reduction is considered. Attention is focused on the arguments in favour of free-trade and protectionism, as well as the positive and negative consequences of implementing the export-oriented growth strategy. The main conceptual approaches to the study of the impact of international trade liberalization on the economic situation of the developing countries are grouped together. Based on the analysis, it has been shown that the concept of ultra-liberalism is unacceptable for the development of Periphery countries in the context of increasing their welfare. The focus is on the implementation of an export-oriented strategy for the development of poor countries, and these groups of Periphery countries are presented, where this strategy can be successful. The main reasons for the low efficiency of export expansion of developing countries are determined, and the directions of its increase are proposed, which concern, first and foremost, the need for the internal institutional transformation of these countries.
\end{abstract}

(C) Viktoriia Adamyk, 2017.

Adamyk Viktoriia, Cand. of Econ. Sciences, Assist. Prof., Lviv Polytechnic National University, Ukraine. 


\section{Key words:}

Developing countries, Center and Periphery countries, foreign trade policy, free trade, protectionism, ultra-liberalism, neocolonialism, import substitution, export-oriented strategy, "curse of natural resources», "Dutch disease», paradigm of «flying geese».

JEL: F13.

\section{Introduction}

For many decades, discussion in the scientific community is not suppressed about the choice of an optimal foreign trade strategy for the developing countries. This discussion has often changed its direction under the influence of the transformation of the geosystem (getting independence from former colonies, the emergence of transitive economies, the collapse of several states of the socialist camp) and international economic policy, caused, first of all, by the aggravation of global economic instability and the permanent search for ways to overcome poverty in most so-called «Peripheral» countries $^{1}$ (real and financial crises, the introduction of the concept of ultraliberalism (enshrined in the Washington Consensus) and disappointment in it, the emergence of new integrational associations, including these in the developing countries, the deepening of global humanity problems, primarily the problem of economic marginalization of the world, and poverty.

It should be noted, that in this paper we will concentrate on the issues of foreign trade policy of the countries with problems of poverty (in other words, poor countries) with the aim to find out how exactly economic and political levers of regulation of international trade can weaken or exacerbate the manifestations of poverty. The paper is a continuation of our previous research, in particular those relating to the impact of poverty on the welfare of the population (Adamyk, Savka, 2006), the theoretical and practical determinants of changing the direction of international trade policy (Adamyk, 2007), the use of trade instruments of in-

\footnotetext{
${ }^{1}$ In this study, we consider it appropriate to identify the concept of «developing country» and «country of the periphery».
} 

in the context of searching the ways to reduce poverty

ternational poverty reduction policies to support food security (Adamyk, 2009) etc.

Regardless of the periodic, sometimes, sharp, corrections of vectors of scientific reflection on the choice of the most rational alternative to foreign trade policy over the past decade; there can be distinguished several key aspects of this problem, which today are most urgent for poor countries. They include: the search for relevant arguments in favour of liberalizing international trade or protectionism, justifying the expediency or danger of export-oriented policy, the effectiveness of a particular strategy of the country's participation in international trade, depending on the adequacy of the chosen instrument. These questions were reflected in the publications of domestic and foreign scientists: as a result, the modern methodological base for the study of the country's choice of foreign trade strategy has been shaped by A. Bue, K. Akamatsu, R. Prebish, G. Singer, P. Krugman, V. Ojimi, S. Furtado, and the applied issues of the implementation of various types of international trade policy are covered in the works of G. Bannister, K. Thugge, J. Nash, D. Mitchell, A. Larson, V. Sereda, L. Martyniuk, I. Ivaschuk, I. Puzanova, N. Karasiova, L. Kapitsa and other domestic and foreign researchers.

However, as a rule, the works of the abovementioned scientists provide arguments in favour of one or another form of international trade policy in relation to developing countries, while the purpose of our study is to consider different points of view on this problem, and, through the prism of the use of trade and political levers for overcoming poverty in Periphery countries.

\section{Trade liberalization versus strengthening protectionism}

The argument in favour of international trade liberalization in the context of the search for mechanisms for poverty reduction in the developing countries became very top requested in the era of the Washington Consensus, but in recent decades has been transformed into a discussion with emphasis on the existence of controversial aspects («pitfalls») of comprehensive liberalization. In fact, at the beginning of the 21 st century, there were three main points of view on the impact of free trade on the development of countries with poverty problems. The first of these is based on the orthodox theories of international trade, which emphasize the effectiveness of the free trade regime as a means of rational allocation of resources, and therefore - stimulating economic growth. This concept has found many supporters, especially among experts from international economic organizations, in particular the WTO, the IMF and the World Bank, who have promoted the idea of ultraliberalism in the economy, including in the field of trade, reason- 
ing it over the years, as an extension of the volumes and shares of the developing countries in world trade. Thus, according to the WTO data, the export volumes of the developing countries during the period of 1990-2008 (during the most rapid opening of their markets) increased from 221.1 billion USD $(29 \%$ in world exports) to 2773.7 billion US dollars (47\%) with the global economic crisis leading to a relatively smaller drop in exports of developing countries compared to a similar indicator of the developed countries. A. Larson, one of the most uncompromising supporters of free-trade, notes that economic growth in those developing countries that lowered trade barriers in the 1980-90s was 3-5\% annually, while income inequality did not increase (Larson, 2001) .

However, it should be emphasized again that the developing countries are not a homogeneous group on the level of well-being and other poverty criteria. Thus, the share of exports of the least developed countries remained very small (only $2.8 \%$ in 2009 in the group of the developing countries, despite a significant increase in exports from \$18 million in 1990 to \$225 million USA dollars in 2009) (Electronic resource).

Recognizing the importance of opening up their markets for imports from the poorest countries of the world, almost all developed countries, with the exception of the US and South Korea (in relation to the latter there is a positive trend), minimized customs barriers to all products of underdeveloped countries, in particular with respect to their main export products - textile, clothing and agricultural products (see Table 1).

In response to the warnings about the ineffectiveness of the multilateral liberalization of international trade for all countries in the context of poverty reduction, the apologists of the idea of its necessity, in particular G. Bannister and $\mathrm{K}$. Thugge, argue that it is not a free trade that leads to a deterioration in the socio-economic situation of the poor countries, but non-rational «preliberalization» restrictions. Relying on empirical research, the scientists insist that a possible decline in wealth as a result of trade liberalization occurs only in the short run, and the dynamic effects of opening commodity markets are more significant than static ones (Bannister, Thugge, 2001).

It should be noted, that in favour of the policy of free-trade for the reduction of poverty, we can cite a lot of arguments, confirmed by theoretical developments and practice. Thus, the choice in favor of reducing trade barriers, as it was already mentioned above, opens access of poor countries to the large markets of developed countries, provides an inflow of export revenues, and thus facilitates the servicing of external debt, and reduces the need for new borrowings, ensures the supply of food products and goods of prime necessity for lower prices (reduces the cost and improves the quality of the consumer basket of the population), as well as reduces investment import, contributing to the modernization of production. With some reservations, we agree with the conclusions of J. Nash and D. Mitchell on the danger of the use of protective measures primarily in the agricultural sector, since the temporary positive effect of the redistribution of in- 

in the context of searching the ways to reduce poverty

come for the support of domestic farmers (very doubtful under the conditions of the rule of archaic methods of production) in the long run will be eliminated by the non-rational use of resources and probable trade conflicts with trade partners and even trade wars (Nash, Mitchell, pp. 35-37). As a confirmation of this view, we will highlight the fact that most poor countries are exporters of agricultural products, while a significant part of their population is suffering from hunger.

Table 1

Access of the poorest countries to the markets of the developed countries

\begin{tabular}{|c|c|c|c|c|c|c|c|c|}
\hline \multirow{3}{*}{$\begin{array}{l}\text { Industrially } \\
\text { developed } \\
\text { country / } \\
\text { country } \\
\text { association }\end{array}$} & \multirow{2}{*}{\multicolumn{2}{|c|}{$\begin{array}{l}\text { Share of goods } \\
\text { (with the ex- } \\
\text { ception of } \\
\text { weapons) ex- } \\
\text { empted from } \\
\text { customs duties }\end{array}$}} & \multicolumn{6}{|c|}{$\begin{array}{c}\text { Average import tariffs } \\
\text { from least developed countries }\end{array}$} \\
\hline & & & \multicolumn{2}{|c|}{$\begin{array}{l}\text { Agricultural } \\
\text { Products }\end{array}$} & \multicolumn{2}{|c|}{ Textile } & \multicolumn{2}{|c|}{ Clothing } \\
\hline & 2007 & 2014 & 2007 & 2014 & 2007 & 2014 & 2007 & 2014 \\
\hline Australia & 100,0 & 100,0 & 0,0 & 0,0 & 0,0 & 0,0 & 0,0 & 0,0 \\
\hline Canada & 99,9 & 99,8 & 0,1 & 0,1 & 0,2 & 0,2 & 1,7 & 1,7 \\
\hline $\begin{array}{l}\text { European } \\
\text { Union }\end{array}$ & 98,3 & 99,0 & 1,4 & 0,1 & 0,1 & 0,1 & 1,2 & 1,3 \\
\hline Japan & 99,6 & 99,3 & 1,2 & 0,7 & 2,6 & 2,2 & 0,1 & 0,2 \\
\hline $\begin{array}{l}\text { Republic } \\
\text { of Korea }\end{array}$ & 37,1 & 87,8 & 29,7 & 14,6 & 8,8 & 0,0 & 8,9 & 0,1 \\
\hline New Zealand & 98,7 & 98,7 & 0,0 & 0,0 & 0,0 & 0,0 & 0,0 & 0,0 \\
\hline Norway & 99,9 & 100,0 & 0,2 & 0,0 & 0,0 & 0,0 & 1,0 & 0,0 \\
\hline Switzerland & 96,2 & 100,0 & 3,1 & 0,0 & 0,0 & 0,0 & 0,0 & 0,0 \\
\hline USA & 78,9 & 61,3 & 5,8 & 5,6 & 5,7 & 5,7 & 11,3 & 11,3 \\
\hline
\end{tabular}

Source: Grouped by author by: World Development Indicators 2016 (Electronic resource) Access mode: http://wdi.worldbank.org/table (Electronic resource, 2016).

Exploring the impact of multilateral liberalization of international trade after the Uruguay Round on the developing countries, W. Martin points out the following: as a result of lower customs tariffs introduced by the developed countries, the developing countries have won 43 billion US dollars (including 12 billion by reducing barriers to agriculture), while the benefits for the developed countries from foreign trade liberalization in emerging economies amounted to about $\$ 50$ billion USA (mainly in the field of textile and clothing trade) (Martin, n. d., 
p. 91). Taking into account the considerably larger share of the developed countries in world trade in comparison with the developing countries, there can be noted the parity effects of «post-Uruguayan» customs liberalization for both groups of countries. However, this analysis did not take into account the impact of other, non-tariff, and protectionist measures on the welfare of the countries in the world, in particular antidumping duty or tools of latent protectionism.

Opponents of the ultra-liberalism concept in international trade argue that the refusal of protectionism exacerbates the competitive struggle at the domestic level, which leads to the collapse of entire sectors of the national economy that are important for solving social issues. In addition, radical liberalization can lead to higher prices for food products, and will negatively affect the welfare of the poor, which determines the need for significant changes in domestic and international economic policies, in particular the intensification of external assistance.

Conduct of the Doha Round of WTO negotiations and consolidation of the Seoul Consensus concept initiated new principles of international economic policy towards the developing countries aimed at providing them with more favorable conditions for participation in world economic processes. In particular, in order to prevent the decline of certain socially important sectors and sub-sectors of the economy, it is proposed to use certain measures to protect national producers (within the limits of the WTO allowed). Thus, in India, China and Brazil, there is maintained the mechanism for supporting small farmers through the application of a special duty in the event of an increase in imports or falling prices.

However, the industrialized countries, on the one hand, have opened their markets to less economically successful partners by lowering import tariff rates (especially from the least developed countries (LDCs) - from an average of $4 \%$ in 2005 to $3 \%$ in 2015 . At that, the duty on finished products decreased from $3.6 \%$ to $2.2 \%$ respectively, and on agricultural raw materials, on the contrary, increased from $1.8 \%$ to $9.5 \%$ (Electronic resource, 2016), and, on the other hand, intensified the use of hidden and collective protectionism (on the part of integrational entities). In particular, despite A. Merkel's statement about the obstacles to the development of international trade and economic growth, created by protectionist measures (Merkel, 14.06.2012), the EU during 2011-2013 was the leader of the number of trade restrictions introduced 69 (trade restrictions.) thus, the second place took the USA (57 t. r.), and the third - China (34 t. r.) (Serpukhov, 2013, pp. 23-27).

It should be noted, that the countries that are developing at medium and slow pace are also increasingly resorting to protecting domestic producers, including non-tariff ones, however, unlike the developed and fast-growing countries (growing markets), which mainly use the authorized by the WTO possibility of temporarily increase of customs (anti-dumping and countervailing duties - USA, EU, China), and tools of hidden protectionism (for example, requirements for the share of domestic production components in Australia and China, state orders in France, Italy, Viet-Nam and China, access restrictions in Brazil), the countries of 

in the context of searching the ways to reduce poverty

the Periphery use financial methods (subsidized lending - South Korea, Taiwan (in the past century), some Latin American countries, export subsidies - Columbia, Uruguay) and technical barriers - India, Columbia, Russia), and some of them - currency levers of influence on export opportunities (Kazakhstan) (Enej, n. d; Serpukhov, 2013, p. 25). It should be noted, that the intensification of protectionist behavior in a group of developing countries calls into question the success of one of the possible directions of using international trade, namely, its revitalization among the countries of the group as a mechanism for improving their well-being.

As stated above, a significant challenge to the liberalization of international trade is the regionalization of global economic development. Successful regional trade entities created primarily by large, economically strong countries, which, by increasing protectionist barriers, are strengthening their positions on the world market, while many weaker counterparts suffer from the effects of trade diversion. In particular, N. Reznikova adheres to this opinion (Reznikova, 2013, pp. 350-351). We come to a paradoxical conclusion: the members of the integration blocks, erasing within their borders obstacles to the movement of goods and services, form a powerful protectionist lobby on a global scale (see the above statistical data).

Given the reality, a number of politicians, scientists and specialists from international organizations have formulated a modified concept of global free trade, which can be described as «moderate protectionism», in other words, the liberalization of trade with a number of exceptions and «special conditions». That is, on the one hand, the developing countries (Peripherals) are allowed to gradually open markets to foreign competitors, and, on the other hand, the developed countries (the Center) reserve the right to protect their interests and warn the socalled «reverse» discrimination ${ }^{2}$. In theory, such an approach is designed to promote the development of poor countries as pioneering trade partners, and to prevent false competition and the monopolization of individual industries globally. But in practice the desire to preserve their shares in world trade has slowed down the Doha Round negotiations (which began in 2001 and is still ongoing), transforming it from the development round into the dispute between the EU and the US for the markets of sales, and activating hidden protectionism (which instruments are not controlled by the WTO).

Against the background of the discussion above, the arguments in favour of the concept of neo-colonialism do not seem foolish.

The term of «neo-colonialism» and its theoretical rationale appeared in the late 1950 s of the $20^{\text {th }}$ century, but in recent years this concept has gained a new dimension, primarily as an explanation of the inevitability of social divergence in

\footnotetext{
2 In particular, during the Uruguay Round, there was mentioned the so-called «Social dumping " - the sale of goods from tne developing countries at prices lower than the world ones, due to low wages of workers.
} 
ISSN 2519-4070

the modern global space. The influence of the developed countries on the participation of underdeveloped countries in international trade is produced through various channels - from direct influence on the government to conclude agreements on voluntary export restrictions in exchange for preferential loans (in the late 1970 s it became one of the reasons for the international liquidity crisis) to the indirect control of the production and export activities of the Periphery country by international organizations and with the help of TNCs, as well as the reduction of demand for goods of poor countries, especially for fuel and agricultural products, which significantly worsens their terms of trade in the long run ${ }^{3}$. Thus, Y. Enei and A. Filipenko, studying the issues of the foreign policy of Latin America in the 1960-90s, came to the conclusion that the opening of their markets during the period of domination of the ideas of the Washington Consensus (in 1980-1991) led to an increase of import volumes by $23 \%$ and prices for it by $6 \%$, while exports grew by $37 \%$, but prices fell by $78 \%$ (Filipenko, 2000, p. 581). This, according to scientists, was due to the forced curtailment of industrial policy in the mentioned region (vulnerable domestic production was not able to compete with imports), which made it «a raw material appendage of the developed countries of the world» (Enej, n. d., p. 6).

Essential prerequisites for implementing the policy of neo-colonialism have been created by a specificity of the agrarian development of poor countries. On the one hand, the implementation of active reforms in this area at the background of trade liberalization encouraged the influx of foreign capital, and hence, the strengthening of control by TNCs, which had already virtually covered the whole primary sector of underdeveloped countries. In particular, J. Guyatt provides data on the share of exports from Africa, controlled by 15 largest TNCs, namely: 90$95 \%$ - iron ore mining; $80-90 \%$ - cotton, tobacco, wheat, coffee, groats, cocoa; $80-85 \%$ - copper, tin, bauxite, tea; $75 \%$ - oil; $70 \%$ - rice (Guyatt, 2016).

In spite of the above, we note that the concept of neo-colonialism is often mentioned for the purpose of political manipulation and promotion of the struggle against the US hegemony in global development (in the $21^{\text {st }}$ century this concept has gained a special dimension in Russia). Of course, despite the declared «Goals of Sustainable Development», the motives of most international economic agents, both at micro and macro level, are devoid of altruism. However, the developed countries of the world nevertheless gradually open their markets for products from low-income countries, as evidenced by the above statistics. In addition, we would like to emphasize that often the use of all the benefits of trade liberalization is hampered by the inefficient internal and external economic policies of poor countries against the backdrop of the weakness of state institutions with its extreme manifestations, i. e. the pathological dependence on external financial infusions, klepotocracy, the sale of local strategic alliances to foreign owners, etc.

\footnotetext{
${ }^{3}$ The short-term deterioration of the terms of trade by scientists is not considered a negative phenomenon, since it is mainly due to the devaluation of the national currency, which, in favorable circumstances, leads to further improvement of the current account balance of payments.
} 
Table 2

Conceptual approaches to the study of the liberalization of international trade impact on the economic situation of the developing countries

\begin{tabular}{|c|c|c|}
\hline $\begin{array}{l}\text { Scientific con- } \\
\text { cept/theory }\end{array}$ & $\begin{array}{l}\text { Modern represen- } \\
\text { tatives (scientists) }\end{array}$ & $\begin{array}{l}\text { Arguments for the benefit of / } \\
\text { against liberalization }\end{array}$ \\
\hline $\begin{array}{l}\text { Ultra-liberalism } \\
\text { (complete removal } \\
\text { of tariff and non-tariff } \\
\text { barriers by both de- } \\
\text { veloped and unde- } \\
\text { veloped countries }\end{array}$ & $\begin{array}{l}\text { G. Bannister, } \\
\text { A. Larson, } \\
\text { D. Mitchell, } \\
\text { K. Thugge, } \\
\text { J. Nash }\end{array}$ & $\begin{array}{l}\text { Opening markets provides satisfac- } \\
\text { tion of consumer demand and } \\
\text { warns of food crisis. Free trading } \\
\text { stimulates the domestic commodity } \\
\text { producer to raise the quality of pro- } \\
\text { duction in order to withstand foreign } \\
\text { competition. The increase in ex- } \\
\text { ports of poor countries contributes } \\
\text { to addressing a number of poverty } \\
\text { issues, in particular the reduction of } \\
\text { external debt. }\end{array}$ \\
\hline $\begin{array}{l}\text { Moderate } \\
\text { protectionism } \\
\text { (Use of exceptions } \\
\text { and reservations in } \\
\text { compliance with the } \\
\text { principles of the } \\
\text { WTO, including in } \\
\text { accordance with the } \\
\text { ideas of the Seoul } \\
\text { consensus). }\end{array}$ & $\begin{array}{l}\text { A. Merkel, } \\
\text { M. Serpukhov, } \\
\text { Ya. Enei, } \\
\text { V. Sereda, } \\
\text { L. Martyniuk, } \\
\text { A. Filipenko }\end{array}$ & $\begin{array}{l}\text { Conditions of trade in developing } \\
\text { countries are permanently worsen- } \\
\text { ing; their improvement is possible } \\
\text { under condition of effective protec- } \\
\text { tionist protection. The «preferential» } \\
\text { mode of opening markets will main- } \\
\text { tain the competitiveness of national } \\
\text { producers of Periphery countries. } \\
\text { Control over the use of protectionist } \\
\text { measures by the WTO is possible } \\
\text { provided that the possibilities of us- } \\
\text { ing the customs controls of the do- } \\
\text { mestic producer are expanded. }\end{array}$ \\
\hline $\begin{array}{l}\text { Neo-colonialism } \\
\text { (dominance of the } \\
\text { interests of the Cen- } \\
\text { ter countries in the } \\
\text { formation of the sys- } \\
\text { tem of international } \\
\text { trade and global } \\
\text { economic interde- } \\
\text { pendence) }\end{array}$ & $\begin{array}{l}\text { R. Prebish, } \\
\text { I. Valerstein, } \\
\text { E. Goldsmith, } \\
\text { T. Evans A. Miller, } \\
\text { I. Pusanov, } \\
\text { N. Reznikova, } \\
\text { J. Stiglitz }\end{array}$ & $\begin{array}{l}\text { Markets of the developing countries } \\
\text { use for the sale of goods from in- } \\
\text { dustrialized countries and are fully } \\
\text { controlled by the latter. Trade } \\
\text { openness and encouragement of } \\
\text { the establishment of TNC affiliates, } \\
\text { in a context of economic backward- } \\
\text { ness, stimulates imports and trans- } \\
\text { forms the underdeveloped country } \\
\text { into a «raw material appendage» of } \\
\text { rich countries. Free trading } \\
\text { strengthens the dependence of the } \\
\text { small poor countries on the financial }\end{array}$ \\
\hline
\end{tabular}




\begin{tabular}{|c|l|l|}
\hline \hline $\begin{array}{c}\text { Scientific con- } \\
\text { cept/theory }\end{array}$ & $\begin{array}{c}\text { Modern represen- } \\
\text { tatives (scientists) }\end{array}$ & \multicolumn{1}{|c|}{$\begin{array}{c}\text { Arguments for the benefit of / } \\
\text { against liberalization }\end{array}$} \\
\hline \multirow{5}{*}{} & $\begin{array}{l}\text { assistance of large countries, di- } \\
\text { rectly and indirectly (through inter- } \\
\text { national economic organizations). } \\
\text { The tendencies are observed to } \\
\text { monopolize the production of many } \\
\text { types of products. Cheap imports } \\
\text { (not protected by tariff and non-tariff } \\
\text { barriers) produce a negative impact } \\
\text { on the competitiveness of national } \\
\text { producers. Economic growth has a } \\
\text { pronounced «impoverished» char- } \\
\text { acter. }\end{array}$ \\
\hline
\end{tabular}

Note: Developed by the author.

\section{Export Oriented Policy: Benefits and Threats}

At the first glance, the introduction of a free trading policy globally, that gained the institutional support through the Washington Consensus and GATT / WTO international trade regulation, as well as rapid scientific and technological progress, and the liberalization of capital flows has created a solid basis for expanding exports to the developing countries (See fig. 1). Indeed, on the one hand, the aforementioned factors, as well as the reform of the agricultural sector, structural changes in industry, the desire to take its niche in the world market and obtain from it the maximum profits, in particular, to improve the balance of payments and accelerate the rate of economic growth prompted the countries of Asia, Africa And Latin America to try to implement an export-oriented strategy.

However, on the other hand, macroeconomic instability, structural imbalances and institutional weaknesses in the Periphery countries have prevented successful implementation in most of them. The biggest problem remains inefficient, formed spontaneously, without taking into account the principle of competitive advantages, the structure of exports, dictated, firstly, by the insignificant innovation potential of exporting countries, and secondly, the so-called « curse of natural resources» - a phenomenon first described by R. Auty (Auty, 1993, pp. 77-78), which pointed to a negative correlation between the availability of significant reserves of raw materials and favorable conditions for their obtaining (minerals, agricultural land, etc.) in poor countries and their rate of economic 
growth. The existence of this paradox in the global trading space has been confirmed by further research, for example, see (Badeeba, March, 2017, pp. 123124; Kapitsa, n. d.), whose authors point to a number of reasons for this situation, namely: volatility of commodity prices on world markets; aggravation of the conflict between social and ethnic groups regarding the possession of natural resources; irrational industrial and investment policies of the state, which in its turn leads to an aggravation of another phenomenon, i. e. - the "Dutch disease", and hence - the de-industrialization of the national economy and the deterioration of the current account balance of payments.

\section{Fig. 1}

\section{Share of countries in world exports of goods, \%}

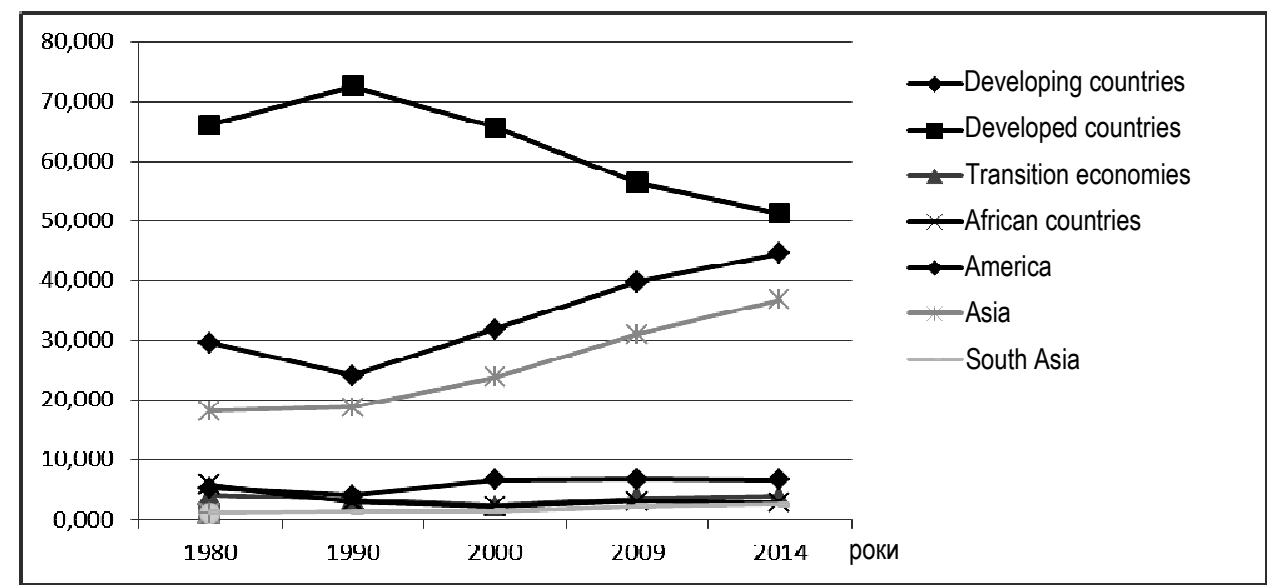

Source: Built by the author after UNCTAD Handbook Statistic 2015 // unctad.org/en/publications Library/tdstat40_en.pdf.

The study of the results of scientific research by leading international scientists and the own analysis of the developing countries practice made it possible to conditionally identify two categories of "peripheral» states, where the implementation of export-oriented policies is potentially successful.

The first of these include the states that are able to supply the world market with either strategically important goods, at that being big countries not only according to the functional criterion, but also by institutional and political one (US, OPEC countries), or with those volumes of products that provide significant effect 
of scale (cost savings for production primarily due to cheap labor - China). Regarding the first factor, we note that in recent decades, the manipulation of commodity prices is one of the manifestations of concentrated interest games on a global scale, while it is due rather to political than economic reasons (for example, the decline in world oil prices in 2014 as a desire to worsen the situation of Russia in the world economic and political arena). Regarding the second factor, it should be emphasized that the success of the export expansion of the developed countries at this stage of the world economic system development provides, first of all, the so-called «technological gap».

The second group includes the developing countries, where the exportoriented strategy is implemented as a result of effective import substitution. In this context, it is necessary to remember the «Flying-Geese paradigm» developed by K. Akamatsu, a kind of catching-up development concept that consists in the formation of three cycles of economic development: 1) increasing of investment imports for the development of national production; 2) the gradual increase in sales in the domestic market, and as it is saturated - access to foreign markets (stage 3). Such a policy is consistent with S. Linder's theory of the uniqueness of demand and the model of competitive advantage of M. Porter, in other words, an increase in exports is possible only in the countries with strong domestic demand («Flying geese paradigm», n. d.). Apologists of import substitution use, in particular, the arguments of V. Ojimi, who, based on Japanese practice has shown that the departure from the principle of "comparative advantage» and the introduction of support of domestic innovative and capital-intensive industries with high elasticity of demand for income creates the basis for effective exportoriented growth (Ojimi, 1970). In addition, an example is also the «new industrial» states - the so-called «growing markets» with a high share of so-called «technological» human capital in labor resources and rapid informatization of society, who at one time also relied on the paradigm of K. Akamatsu, effectively implemented export-oriented strategy, and left the circle of Periphery countries and won a place among the countries of the Center (Kasahara, n. d.).

At the same time, L. Kapitsa, relying on the works of Western scientists, points to the danger of import substitution in the underdeveloped, but rich in natural resources countries. Thus, the intensive industrialization, provided by subsidizing of newly created enterprises and other protectionist measures, promotes a rent-oriented behavior of industrial groups and the formation of a powerful lobby, not interested in the development of other industries, including socially important ones (Kapitsa, n. d., p.172). An example of the failed import substitution experience is the countries of Latin America, which, in the hope of intensifying the domestic investment, had protected the development of domestic production from foreign competition and seemingly achieved significant success, which allowed gradually increasing export volumes. However, import substitution took place only in light industry, and the so-called «investment» goods required for the activity of foreign TNCs, were imported. Accordingly, most of South American states 

in the context of searching the ways to reduce poverty

remained the exporters of predominantly agricultural raw materials and consumer goods with a low share of the innovation component.

It should be noted, that the raw materials of the agrarian sector are the most vulnerable export commodities of the poor countries in the conditions of globalization, and scientific and technological progress. Thus, the share of agricultural raw materials in the total exports of sub-Saharan African countries (traditionally the poorest countries in the world) declined from 5.3 to $2.2 \%$ in the period of 2000-2015, and that of Latin American countries (the largest exporters of agro-industrial products), respectively, from 3\% to $2.8 \%$ (World Development Indicators, 2016), which is due to the intensification and modernization of agricultural production in the developed countries of the world, and hence, due to the decrease of demand in the world market.

Similar threat is also expected in relation to the demand for fuel and some other mineral resources exported by the Periphery countries, as far as the rapid innovation of the Center's countries, the introduction of new technologies, and the ecologization of production gradually reduce the need for traditional types of resources. Regarding fuel, this factor is actualized slowly due to the existence of a powerful industrial lobby with specific interests in the global economic arena.

In the last two decades there has been observed a significant shift in a global demand for investment goods for services, primarily in the IT field. However, the poorest countries in the world, unfortunately, are beyond the limits of the informatization processes. Thus, the share of computer, information, communication and other types of commercial services in the overall structure of exports of services in the low income countries was 30\% per capita in 2015, and in sub Sahara African countries declined from $18 \%$ to $15 \%$ respectively between 2005 and 2015, while that index in the world reached 43\% (in 2015) (World Development Indicators, 2016).

Thus, there can be distinguished the following four main negative effects of the implementation of an irrational export-oriented strategy in Periphery countries, which do not allow it to be considered an effective instrument of international poverty eradication policy:

1) preservation of the primitive structure of production, exhaustion of natural resources and their realization in the world market, even at unprofitable prices or use for the production of only 1-2 products, which leads to an exacerbation of the so-called «impoverished growth»;

2) aggravation of the above-mentioned «Dutch disease», that is, the development of only the first (raw) industrial sector / and 1-2 of service sectors, attraction of foreign capital only in these sectors in excess volumes from the macroeconomic point of view, which leads to the revaluation of the national currency

\footnotetext{
${ }^{4}$ Dependence of the country's GDP on the dynamics of world price for its export commodity.
} 
(Adamyk, 2016, pp. 113-123) («Groningen effect»). «Dutch disease» has negative social effects: it raises the demand for real estate, which in its turn, increases the price of housing and, consequently, inflation, which adversely affects the purchasing power of the country's citizens and the international competitiveness of the country;

3) increasing of the manifestation of one of the generalized characteristics of poverty of the country - the so-called «economic dualism», i.e. an increase in the income gap between the export-oriented industry workers and those involved in the «secondary» sectors that are deprived of investment support. A striking example is China, which in the period from 1980 to 2014 increased its share in world commodity exports from $0.883 \%$ to $12.236 \%$ (UNCTAD Handbook Statistics 2015), while the difference in incomes between the rich and the poor during that period increased fourfold (Electronic resource, 2014) (according to official statistics of China, the Gini coefficient in 2012 was 0.474 , that is, exceeded the social safety margin (Electronic resource, n. d.). The threat of the exportoriented impact on the welfare of the country is even greater in the least developed countries of Africa and South-East Asia, where local population is practically not involved in the technology intensive fields, and the businesses are owned by foreign multinationals;

4) the danger of exacerbating the implications of hidden protectionism by counterparty countries (raising standards of quality and internal taxes and fees, promoting the consumption of local «environmental» products, etc.), the use of their currency warfare and anti-dumping tools, which in the end may lead them to be driven out of the market by the aforementioned industrial lobby of the developed countries.

\section{Conclusions and perspectives for future research}

The study made it possible to formulate the conclusion that it is necessary not only to transform the international trade policy in order to guide it towards achieving the «goals of sustainable development» and to reduce social divergence on a global scale, but also to substantially reform the internal economic strategy of the Periphery countries to ensure the prerequisites for effective integration into the world trading system. The main directions of rationalization of foreign trade policy of the developing countries are defined the following:

1) diversification of the economy and / or exports. Export diversification without structural changes in the peripheral economy can only produce a shortterm positive effect, somewhat reducing the negative impact of price volatility on the world market, since, as practice shows, the expansion of the range of export 

in the context of searching the ways to reduce poverty

products will be due to several raw materials or products / services with little technological constituent, that is, low added value. Economic or production differentiation will be based on the innovative development of the economy, the intellectualization of production processes, and, consequently, will increase the need for highly skilled labor with all positive social consequences and increase the competitiveness of export goods and services on the world market. Alternatively, there can be considered deepening specialization in peripheral exporting countries based on extractive sector modernization and accompanied by the development of an associated service sector (primarily financial and tourism services) - the success of this option is doubtful in the long run, given the exhaustion of natural resources and the ineffectiveness of public administration (exception - the countries of the Persian Gulf and some other OPEC members);

2) shifting the emphasis in investment policy, namely, attracting foreign direct investment in non-raw materials industries, especially in the sphere of services, and development of new technologies. The realization of this trend implies, first, the intensification of efforts to build the market infrastructure in the developing countries, in particular the creation of venture funds, including under the auspices of regional development banks (Kapitsa, n.d., p.177-178), and secondly, the application of effective monetary instruments in order to prevent probable negative pressure of capital inflows on the balance of payments;

3) strengthening of state institutions in the underdeveloped countries and reducing the interest of individual officials in rental income, which would allow the possible suspension of the intensive exploitation of natural resources and low skilled labor, changes in industrial policy vectors with selective application of protectionist measures, the fight against kleptocracy;

4) implementation of the sectoral policy of import substitution on the principles of moderate protectionism. Consideration of free trading through the prism of the fight against poverty made it possible to ascertain the possibility of raising the level and quality of life of the developing country's citizens only in certain aspects and in the short term (due to cheap imports of goods of prime necessity and / or increase in consumption against the background of the growth of the balance of payments deficit, which, according to the postulates of the theory of intermittent trade, leads to the accumulation of external debt - one of the main reasons for the deepening of poverty of the country). State support and protection should focus on innovative industries and the leveling of market failures.

In view of the proposed directions, the currency and investment aspects of the implementation of foreign trade strategy of the Periphery countries, as well as the issues of its institutional support need further research. 


\section{References}

1. Adamyk, V. V., Savka, A. (2006). Methodological approaches to the study of the link between international trade and the welfare of the population through the «economic growth». Bulletin of TANE. №1, p. 129-135 (in Ukrainian).

2. Adamyk, V. V. (2007). Theoretical and actual determinants of improving the trade levers of international poverty reduction policies. Strategy of development of Ukraine (economics, sociology, law): Scien. Journal, editor in chiefO. P. Stepanov. Kyiv, № 6, p. 17-26 (in Ukrainian).

3. Adamyk, V. V. (2009). Actual issues of food security and agricultural development in the context of poverty reduction. Bulletin of TNEU. № 1. p. 61-69 (in Ukrainian).

4. Larson, A. (2001). Trade liberalization for the purpose of combating poverty. Economic prospects. Retrieved from: http://usinfo.state.gov/journals/ ites/0901/ijek/larson.htm.

5. Millennium development goals. Trade and development. Retrieved from: https://www.wto.org/english/thewto_e/coher_e/mdg_e/development_e.htm.

6. World Development Indicators 2016. Retrieved from: http://wdi.worldbank.org/table.

7. Bannister, G. J., Thugge, K. International Trade and Poverty Alleviation. Retrieved from: https://www.imf.org/external/pubs/ft/wp/2001/wp0154.pd.f

8. Nash, G., Mitchell, D. (March, 2005). How liberalization of trade can help feed the poor. Finance and development. P. 34-37. http://www.imf.org/ external/pubs/ft/fandd/rus/2005/03/pdf.nash.pdf.

9. Martin, W. (n. d.). Trade Policies, Developing Countries, and Globalization. Retrieved from: http://siteresources.worldbank.org/INTGGP/Resources/ 2866_trade_martin.pdf.

10. Merkel, A. (14.06.2012). Protectionism inhibits the growth of the global economy. Deutsche Welle. Retrieved from: www.dw.de/dw/article/ 0,16023317,00.htlm (in Russian).

11. Enej Ya.I. (n.d.). World experience in the implementation of the import substitution policy. Retrieved from: http://dspace.udpu.org.ua:8080/ jspui/bitstream/6789/2492/1/Eney_Yana_Svitovyi_dosvid_zdiisnenia_polityky _importozamischenia.pdf (in Ukrainian). 

in the context of searching the ways to reduce poverty

12. Serpukhov, M. (2013). Covert protectionism as an instrument of modern international trade policy. Economics of Development. № 4 (68), p. 23-27 (in Ukrainian).

13. Rieznikova, N. (2013). Global economic interdependence: the modern paradigm and the determinants of modification. K: Publishing House LLC «VISTKA», p. 456 (in Ukrainian).

14. Philipenko, A. (2000). Economy of the foreign countries. K.: Publishing House «Lybid», p. 581 (in Ukrainian).

15. Kuyaite, J. (2016). The Problem of Neocolonialism in the Modern World (Experience of the Countries of Africa and Russia), Herald of TISBI. Retrieved from: http://www.tisbi.ru/home/science/journal-of-tisbi/2000/4/page-2612 (in Russian).

16. Auty, R. (1993). Sustaining Development in Mineral Economies: the Resource Curse Thesis. Routlenge, London. Retrieved from: https://ideas.repec.org/a/eee/jrpoli/v20y1994i1p77-78.html.

17. Badeeb, R. A. (March, 2017.). The evolution of the natural resource curse thesis: A critical literature survey / R. A. Badeeba, H. H. Leana, J. Clark. Resources Policy. Volume 51, P. 123-134. Retrieved from: http://www.sciencedirect.com/science/article/pii/S0301420716301507.

18. Kapitsa, L. M. (n. d.). Natural resources and socio-economic progress. Retrieved from: https://www.academia.edu/Natural_Resources_and_SocioEconomic_Progress (in Russian).

19. Flying geese paradigm. Retrieved from: https://en.wikipedia.org/wiki/ Flying_geese_paradigm.

20. Ojimi, V. (1970). Japan's industrialization strategy. In OECD, Japanese Industrial Policy, Paris: OECD.

21. Kasahara, S. (n. d.). The asian developmental state and flying geese paradigm// UNCTAD/OSG/DP/2013/3 Retrieved from: http://unctad.org/en/ PublicationsLibrary/osgdp20133_en.pdf.

22. Adamyk, V.V. (2016). Foreign Direct Investment as a Poverty Reduction Instrument in Developing Countries. Bulletin of Ternopil National Economic University. № 2, p. 113-123 (in Ukrainian).

23. UNCTAD Handbook Statistic 2015. Retrieved from: http://unctad.org/en/ publicationsLibrary/tdstat40_en.pdf.

24. Income inequality in China exceeds even US figures (2014). Independent Auditor. Retrieved from: http: http://n-auditor.com.ua/uk/novini/mizhnarodnijoglyad/item/14713.html (In Ukrainian). 
Vol. 16. № 3 (62). July-September 2017

ISSN 2519-4070

25. The Chinese government showed a gap in citizen incomes for the first time. Retrieved from: https://www.ukrinform.ua/rubric-abroad/1446158-uryad_kitayu_vpershe_pokazav_rozriv_u_dohodah_gromadyan_1788163.html.

26. Puzanov, I. I. (2014). Impact of export-oriented and import-substitute strategy on the nature and directions of economic growth. Scientific Bulletin of the National Academy of Statistics, Accounting and Audit. №1, p. 44-52 (In Ukrainian). 